\title{
ANTITUMOR DRUG ELLIPTICINE INHIBITS THE ACTIVITIES OF RAT HEPATIC CYTOCHROMES P450
}

\author{
Dagmar Aimová, Marie Stiborová
}

\author{
Department of Biochemistry, Faculty of Science, Charles University, Albertov 2030, 12840 Prague 2, Czech Republic \\ e-mail:stiborov@natur.cuni.cz
}

Received: June 10, 2005; Accepted: September 25, 2005

Key words: Ellipticine/Anticancer drug/Cytochrome P450/Inhibition/Binding

\begin{abstract}
Ellipticine is a potent antineoplastic agent, whose mode of action is considered to be based mainly on DNA intercalation and/or inhibition of topoisomerase II. Recently, we found that ellipticine also forms the cytochrome P450 (CYP)-mediated covalent DNA adducts. Here, we study the effect of ellipticine on CYP enzymes in rat hepatic microsomes, studying its binding to the enzymes and its potential to inhibit the CYP activities measured with their selective substrates. Although ellipticine was reported to be a selective and strong inhibitor of CYP1A1/2, we found that its inhibitory potential is non-specific. Ellipticine is the most potent inhibitor for CYP3A-dependent $6 \beta$-hydroxylation of progesterone, followed by CYP1A1/2-dependent ethoxyresorufin O-deethylation and CYP2B-mediated pentoxyresorufin O-depentylation. Lower inhibition was detected for 1'-hydroxylation of bufurarol, 21-hydroxylation of progesterone and 6-hydroxylation of chlorzoxazone catalyzed by CYP2D, CYP2C and CYP2E1, respectively. Ellipticine binds to several CYPs of rat hepatic microsomes. The binding titration of ellipticine typically give reverse type I spectrum with CYPs in rat hepatic microsomes. The results indicate that inhibition of CYPs by ellipticine cannot be explained only by its differential potency to bind to individual CYPs.
\end{abstract}

\section{INTRODUCTION}

Ellipticine (5,11-dimethyl-6H-pyrido[4,3-b]carbazole) and several of its derivatives isolated from Apocyanaceae plants (i.e. Ochrosia borbonica, Excavatia coccinea) are alkaloids exhibiting significant antitumor and anti-HIV activities. Ellipticine and its more soluble derivatives (9-hydroxyellipticine, 9-hydroxy- $N^{2}$-methylellipticinium, 9-chloro- $N^{2}$-methylellipticinium and 9-methoxy- $N^{2}$-methylellipticinium) exhibit promising results in the treatment of osteolytic breast cancer metastases, kidney sarcoma, tumors of brain and myeloblastic leukemia (for summary $\left.\mathrm{see}^{1}\right)$. In order to increase the selectivity of ellipticine antitumor drugs, the attempts to link them to specific vectors able to direct these drugs towards target cells, were performed ${ }^{2-4}$. One such conjugate, a heptagastrin fragment linked to ellipticine via a spacer has recently been synthesized and shown to be selectively taken up and to be cytotoxic to cells expressing the cholecystokinin type $\mathrm{B}$ receptor ${ }^{4}$. The main reason for the interest in ellipticine and its derivatives for clinical purposes is their high efficiencies against several types of cancer, their rather limited toxic side effects and their complete lack of hematological toxicity 5 . However, ellipticine and most of its derivatives are mutagenic compounds (for an overview see $^{1}$ ).

Ellipticines are anticancer drugs, whose precise mechanisms of action have not yet been explained. It was suggested that the prevalent mechanisms of ellipticine antitumor activities are (i) intercalation into DNA (ref. ${ }^{6,7}$ ) and (ii) inhibition of DNA topoisomerase II activity ${ }^{8-10}$. Ellipticine and 9-hydroxyellipticine also cause selective inhibition of p53 protein phosphorylation in several human cancer cell lines ${ }^{11}$, and this correlated with their cytotoxic activity. Ellipticines also uncouple mitochondrial oxidative phosphorylation ${ }^{12}$, and thereby disrupt the energy balance of cells.

Recently, we found another mechanism for the ellipticine action ${ }^{1,13-16}$. We demonstrated that ellipticine covalently binds to DNA after being enzymatically activated. Cytochromes P450 (CYP) are the major enzymes catalyzing the ellipticine oxidation and its activation to more efficient metabolite(s) forming DNA adducts. Using a panel of different human recombinant CYPs - CYP3A4, CYP1A1, CYP1B1 - enzymes expressed at higher levels in tumors sensitive to ellipticine (i.e. breast cancer, renal cell cancer) than in peritumoral tissues ${ }^{17}$, were found to be the most effective CYP enzymes activating ellipticine to form covalent DNA adducts in vitro ${ }^{1}$. The formation of this CYP-mediated covalent DNA adduct by ellipticine was also detected in vivo, in rats treated with ellipticine ${ }^{14}$. Based on these data, ellipticine might be considered a pro-drug, whose pharmacological efficiency is dependent on its enzymatic activation in target tissues ${ }^{1,13-16}$.

The discrepancies in data showing oxidation of ellipticine by CYPs and the effects of the drug on these enzymes were observed. On the one hand, ellipticine was found to be a substrate of CYP $\left(\right.$ ref. $^{5,16}$ ) and, moreover, it is also an inducer of several CYPs $\left(\right.$ ref. $^{18}$ ). On the other hand, this compound was reported to be a strong inhibitor of some 
CYPs, selectively inhibiting CYP1A1/2 $\left(\right.$ ref. $\left.^{5}\right)$. Therefore, the aim of the present work is to extend our knowledge on the ellipticine - CYP interaction and its inhibitory effects on the microsomal mixed function oxidase (MFO) system containing the CYP enzymes.

\section{MATERIAL AND METHODS}

\section{Preparation of microsomes and assays}

Microsomes were isolated from livers of untreated rats and those of pre-treated with $\beta$-naphthoflavone ( $\beta$-NF), phenobarbital $(\mathrm{PB})$, ethanol $(\mathrm{EtOH})$ and pregnenolon $16 \alpha$-carbonitrile $(\mathrm{PCN})$ by procedures as described ${ }^{18}$. 7-Ethoxyresorufin O-deethylation (EROD, CYP1A1/2 activity), 7-pentoxyresorufin O-depentylation (PROD, CYP2B activity), progesterone 21-hydroxylation (CYP2C activity), bufuralol 1'-hydroxylation (CYP2D activity), chlorzoxazone 6-hydroxylation (CYP2E1 activity) and progesterone $6 \beta$-hydroxylation (CYP3A activity) were carried out as described ${ }^{19,20}$. The activity of NADPH:CYP reductase was measured using cytochrome $\mathrm{c}$ as substrate (i.e. as NADPH:cytochrome c reductase) ${ }^{19}$.

\section{Spectral measurements}

The binding of ellipticine to CYPs in microsomes was monitored by difference spectroscopy ${ }^{19}$. The concentra- tion of microsomal protein was adjusted to $1.0 \mathrm{mg}$ per $\mathrm{ml}$ of $0.1 \mathrm{M}$ potassium phosphate buffer, $\mathrm{pH}$ 7.4. Ellipticine (0.5-10 $\mu$ l of methanolic stock solution) was directly added to the sample cuvette containing the enzyme system. The same volume of the solvent was added to the reference cuvette. Absorption spectra were recorded at ambient temperature between 350 and $500 \mathrm{~nm}$. The difference in absorbance between the wavelength maximum and minimum was plotted vs the ellipticine concentration, which was analyzed by nonlinear regression methods with Origin 6.0 software. Two equations were compared statistically to determine the best fit: $\Delta \mathrm{A}=\mathrm{B}_{\max } \mathrm{S} /\left(\mathrm{K}_{\mathrm{s}}+\mathrm{S}\right)$ and $\Delta \mathrm{A}=\mathrm{B}_{\max } \mathrm{S}^{\mathrm{n}} /\left(\mathrm{K}_{\mathrm{s}}^{\mathrm{n}}+\mathrm{S}^{\mathrm{n}}\right)$, where $\mathrm{S}$ represents substrate concentration, $\mathrm{K}_{\mathrm{s}}$ is the apparent spectral dissociation constant, $\mathrm{B}_{\max }$ is the maximal binding, and $\mathrm{n}$ is a measure of the cooperativity ${ }^{19}$.

\section{RESULTS AND DISCUSSION}

\section{Ellipticine acts as an inhibitor of cytochromes P450}

Although ellipticine was reported to be a selective and strong inhibitor of CYP1A1/2, we found that its inhibitory potential is non-specific. Control, $\beta$-NF-, PB-, ethanol- and PCN-induced microsomal CYP activities are inhibited by ellipticine. A degree of CYP inhibition by the compound was quantified. Ellipticine is the most potent inhibitor

Table 1. Inhibition of reactions catalyzed by individual cytochromes P450 by ellipticine

\begin{tabular}{|c|c|c|c|c|c|c|}
\hline specific reaction & CYP & $\begin{array}{c}\text { microsomes } \\
\text { - pre-treatement }\end{array}$ & $\begin{array}{c}\mathrm{IC}_{50} \\
\text { ellipticine } \\
\mu \mathrm{M}\end{array}$ & $\begin{array}{c}\text { substrate } \\
\text { concentration } \\
\mu \mathrm{M}\end{array}$ & $\begin{array}{c}\text { inhibition } \\
\text { constant } \mathrm{K}_{\mathrm{i}} \\
\mu \mathrm{M}\end{array}$ & $\begin{array}{l}\text { inhibition } \\
\text { type }\end{array}$ \\
\hline $\begin{array}{l}\text { 7-ethoxyresorufine } \\
\text { O-dealkylation }\end{array}$ & $\begin{array}{l}\text { CYP1A1 } \\
\text { CYP1A2 }\end{array}$ & $\beta$-NF & 0.11 & 2 & $0.038 \pm 0.010$ & $\mathrm{NC}$ \\
\hline $\begin{array}{l}\text { 7-pentoxyresorufine } \\
\text { O-dealkylation }\end{array}$ & CYP2B & $\mathrm{PB}$ & 0.11 & 2 & $0.050 \pm 0.020$ & $\begin{array}{l}\text { mixed } \\
\mathrm{C} / \mathrm{NC}\end{array}$ \\
\hline $\begin{array}{l}\text { progesterone } \\
\text { 21-hydroxylation }\end{array}$ & CYP2C & control & 2 & 50 & *) & \\
\hline $\begin{array}{l}\text { bufuralol } \\
\text { 1'-hydroxylation }\end{array}$ & CYP2D & control & 0.5 & 50 & $0.24 \pm 0.03$ & $\begin{array}{l}\text { mixed } \\
\mathrm{C} / \mathrm{NC}\end{array}$ \\
\hline $\begin{array}{l}\text { chlorzoxazone } \\
\text { 6-hydroxylation }\end{array}$ & CYP2E1 & EtOH & 140 & 50 & $*)$ & \\
\hline $\begin{array}{l}\text { progesterone } \\
6 \beta \text {-hydroxylation }\end{array}$ & CYP3A & $\mathrm{PCN}$ & 0.5 & 100 & $0.021 \pm 0.01$ & $\begin{array}{l}\text { mixed } \\
\mathrm{C} / \mathrm{NC}\end{array}$ \\
\hline
\end{tabular}

$\mathrm{IC}_{50}$ concentration of ellipticine causing $50 \%$ inhibition

$\mathrm{C}$ competitive inhibition

$\mathrm{NC}$ non-competitive inhibition

* for higher values of $\mathrm{IC}_{50}$ the inhibition constant was not determined 


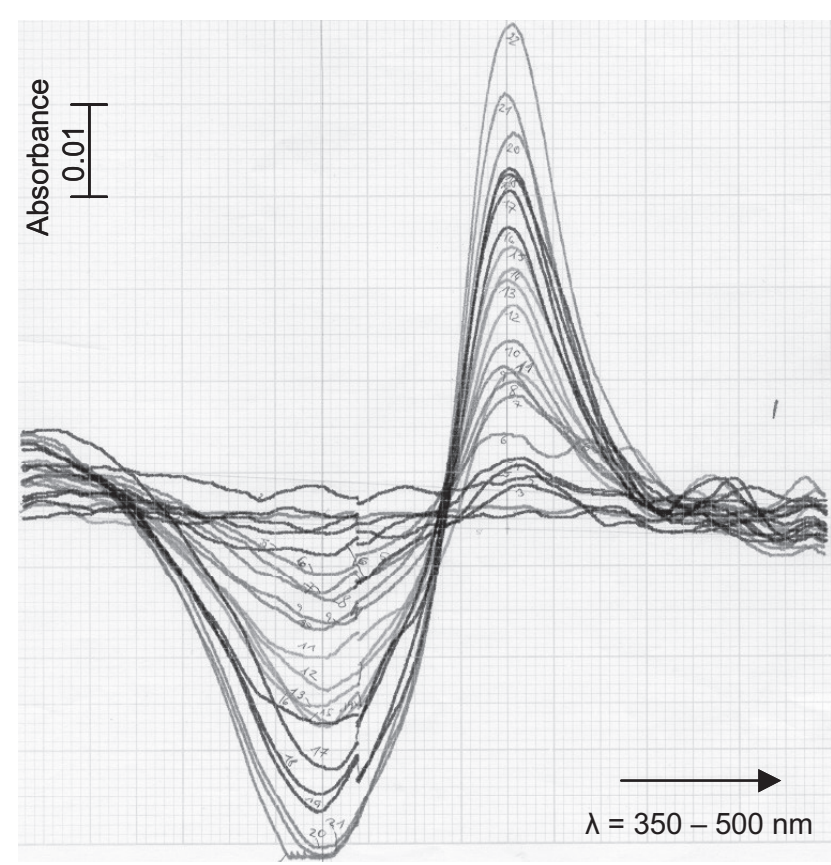

Fig. 1. Ellipticine exhibits a reverse type I binding spectrum with rat hepatic microsomal CYPs (herein with PCN microsomes)

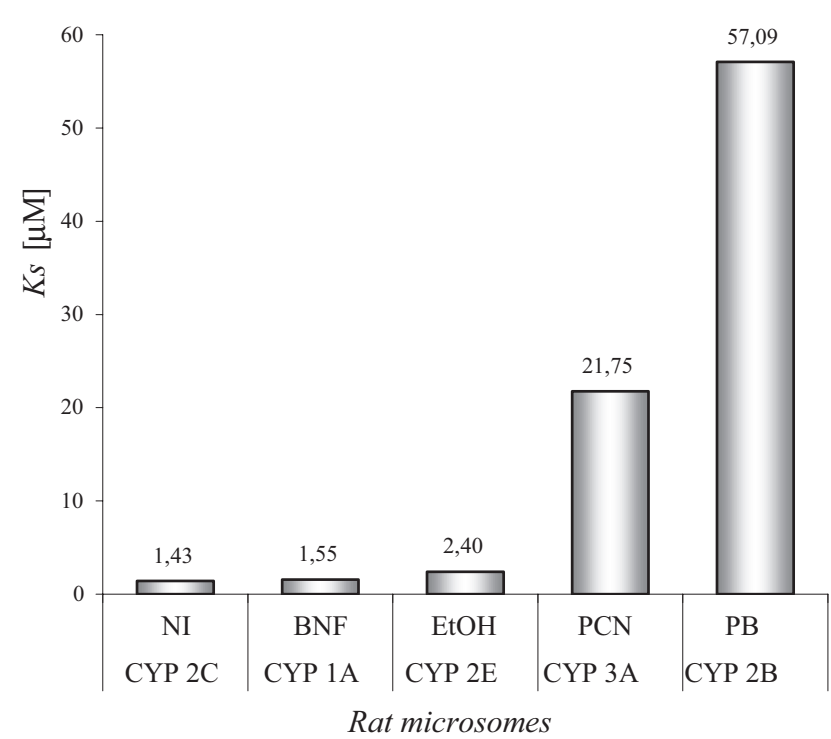

Fig. 2. Apparent dissociation constant $\left(\mathrm{K}_{\mathrm{s}}\right)$ values reflecting the affinity of ellipticine to microsomal CYPs. NI, uninduced; BNF, $\beta$-naphtoflavone; EtOH, ethanol; PCN, pregnenolone $16 \alpha$-carbonitrile; PB, phenobarbital. for CYP3A-dependent 6 $\beta$-hydroxylation of progesterone $\left(\mathrm{K}_{1}=0.021 \mu \mathrm{M}\right)$, followed by CYP1A1/2-dependent EROD activity $\left(\mathrm{K}_{1}=0.038 \mu \mathrm{M}\right)$ and CYP2B-mediated PROD activity $\left(\mathrm{K}_{\mathrm{i}}=0.05 \mu \mathrm{M}\right)$. Lower, but measurable, inhibition was detected for 1'-hydroxylation of bufurarol, 21-hydroxylation of progesterone and 6-hydroxylation of chlorzoxazone catalyzed by CYP2D, CYP2C and CYP2E1, respectively. Ellipticine acts as a non-competitive or mixed-type inhibitor of these enzymes (Table 1).

It should be noted that the interpretation of the results from the inhibition studies is sometimes difficult, because the inhibitor may be more effective with one substrate than another. Therefore, to explain the mechanism of inhibition of CYPs by ellipticine, the binding of ellipticine to microsomal CYPs was examined.

\section{Binding of ellipticine to CYPs in microsomes}

Ellipticine binds to microsomal CYPs with affinity greater than most of other compounds known to interact with these enzymes. It binds to CYPs of microsomes isolated from livers of uninduced rats and from those of rats pre-treated with $B-N F$ (enriched with CYP1A1/2), PB (enriched with CYP2B1/2), PCN (enriched with CYP3A1/2) and ethanol (enriched with CYP2E1). The binding titration of ellipticine typically give reverse type I spectrum $\left(\lambda_{\max } 430 \mathrm{~nm}\right)$ with CYPs in all microsomes tested in the study, measured at $37^{\circ} \mathrm{C}$ (see Fig. 1 for PCN microsomes). This finding indicates that ellipticine interacts both with $\mathrm{Fe}$ of the heme prosthetic group of CYP and with the amino acid residues present in the active centre of the enzyme. The magnitude of the difference of the absorbance maximum and minimum for both compounds is assumed to represent the extent of their binding to the catalytic site. The values of the spectral dissociation constants $\left(\mathrm{K}_{\mathrm{s}}\right)$ for the complexes of ellipticine with CYPs in microsomes, reflecting the affinity of ellipticine to these CYPs are shown in Fig. 2.

As shown from Table 1 and Figure 2, the degree of the CYP inhibition by ellipticine does not correlate with the potency of its binding to the individual CYP enzymes. These results indicate that degrees of inhibition by ellipticine might be explained not only by its differential potency to bind to individual CYP, but also by its effect on another member of the MFO system, e.g. NADPH:CYP reductase. Even though the inhibition of reduction of a non-physiological substrate of NADPH:CYP reductase, cytochrome $c$, was not detected in the presence of ellipticine up to concentrations of $0.5 \mathrm{mM}$ (results not shown), the inhibition of this enzyme using the CYP enzyme as a substrate cannot be excluded. Therefore, the question of the exact mechanism responsible for CYP inhibition by ellipticine remains still to be answered.

\section{ACKNOWLEDGEMENT}

Supported by the Ministry of Education of the Czech Republic (grant 1M4635608802, Centrum of targeted therapeutics). 


\section{REFERENCES}

1. Stiborová M, Bieler CA, Wiessler M, Frei E. (2001) The anticancer agent ellipticine on activation by cytochrome $\mathrm{P} 450$ forms covalent DNA adducts. Biochem Pharmacol 62, 1675-84.

2. Rigaudy P, Charcosset J-Y, Garbay-Jaureguiberry Ch, JacqueminSablon A, Roques BP. (1989) Attempts to target antitumor drugs towards opioid receptor-rich mouse tumor cells with enkephalinellipticinium conjugates. Cancer Res 49,1836-42.

3. Devraj R, Barret JF, Fernandez JA, Katzenellenbogen JA, Cushman M. (1996) Design, synthesis and biological evaluation of ellipticineestradiol conjugates. J Med Chem 39, 3367-74.

4. Czerwinski G, Tarasova NI, Michejda CJ. (1998) Cytotoxic agents directed to peptide hormone receptors: Defining the requirements for a successful drug. Proc Natl Acad Sci USA 95,11520-5.

5. Auclair C. (1987) Multimodal action of antitumor agents on DNA: The ellipticine series. Arch Biochem Biophys 259, 1-14.

6. Singh MP, Hill GC, Peoch D, Rayner, B, Inabach, JL, Lown JW (1994) High-field NMR and restrained molecular modeling studies on a DNA heteroduplex containing a modified apurinic abasic site in the form of covalently linked 9-aminoellipticine. Biochemistry 33, 10271-85.

7. Chu Y, Hsu MT. (1992) Ellipticine increases the superhelical density of intracellular SV40 DNA by intercalation. Nucleic Acids Res 20, 4033-8.

8. Monnot M, Mauffret O, Simon V, Lescot E, Psaume B, Saucier JM, Charra M, Belehradek JJr, Fermandjian S. (1991) DNA-drug recognition and effects on topoisomerase II-mediated cytotoxicity. A three-mode binding model for ellipticine derivatives. J Biol Chem 25, 1820-9.

9. Fossé P, René B, Charra M, Paoletti C, Saucier JM. (1992) Stimulation of topoisomerase II-mediated DNA cleavage by ellipticine derivatives: structure-activity relationships. Mol Pharmacol 42, 590-5

10. Froelich-Ammon SJ, Patchan MW, Osheroff N, Thompson RB (1995) Topoisomerase II binds to ellipticine in the absence or presence of DNA. Characterization of enzyme-drug interactions by fluorescence spectroscopy. J Biol Chem 270, 14998-5004.

11. Ohashi M, Sugikawa E, Nakanishi N. (1995) Inhibition of p53 protein phosphorylation by 9-hydroxyellipticine: A possible anticancer mechanism. Jpn J Cancer Res 86, 819-29.
12. Schwaller MA. Allard B, Lescot E and Moreau F. (1995) Protonophoric activity of ellipticine and isomers across the energy-transducing membrane of mitochondria. J Biol Chem 270, 22709-13.

13. Stiborová M, Stiborová-Rupertová M, Bořek-Dohalská L, Wiessler M, Frei E. (2003) Rat microsomes activating the anticancer drug ellipticine to species covalently binding to deoxyguanosine in DNA are a suitable model mimicking ellipticine bioactivation in humans. Chem Res Toxicol 16, 38-47.

14. Stiborová M, Breuer A, Aimová D, Stiborová-Rupertová M, Wiessler M, Frei E. (2003) DNA adduct formation by the anticancer drug ellipticine in rats determined by ${ }^{32} \mathrm{P}$-postlabeling. Int J Cancer 107, 885-90.

15. Stiborová M, Sejbal J, Bořek-Dohalská L, Aimová D, Poljaková J, Forsterová K, Rupertová M, Wiesner J, Hudeček J, Wiessler M, Frei E. (2004) The anticancer drug ellipticine forms covalent DNA adducts, mediated by human cytochromes P450, through metabolism to 13-hydroxyellipticine and ellipticine $N^{2}$-oxide. Cancer Res 6, 8374-80.

16. Frei E, Bieler CA, Arlt VM, Wiessler M, Stiborová M. (2002) Covalent binding of the anticancer drug ellipticine to DNA in V79 cells transfected with human cytochrome P450 enzymes. Biochem Pharmacol 64, 289-95.

17. Patterson LH, McKeown SR, Robson T, Gallagher R, Raleigh SM, Orr S. (1999) Antitumor prodrug development using cytochrome P450 (CYP) mediated activation. Anti-Cancer Drug Design 14 473-86.

18. Aimová D, Dlouhá T, Frei E, Stiborová M. Anticancer drug ellipticine acts as an inducer of CYP1A1/2 and potentiates its own pharmacological efficiency. In: Anzenbacher P and Hudecek J, editors. Cytochrome P450, Biochemistry, Biophysics and Drug Metabolism.. Bologna: Monduzzi Editore, 2003. p. 133-8.

19. Stiborová M, Bořek-Dohalská L, Hodek P, Mráz J, Frei E. (2002) New selective inhibitors of cytochromes P450 2B and their application to antimutagenesis of tamoxifen. Arch Biochem Biophys 403, 41-9.

20. Bořek-Dohalská L, Hodek P, Šulc M, Stiborová M. (2001) $\alpha$ Naphthoflavone acts as activator and reversible or irreversible inhibitor of rabbit microsomal CYP3A6. Chem-Biol Interact 138, 85-106. 